\title{
KEPALA SEKOLAH SEBAGAI PENENTU KEBIJAKAN PENDIDIKAN DI SEKOLAH DASAR
}

\author{
${ }^{1)}$ Ninik Hidayati, email : ninikhidayati@ stitmatuban.ac.id \\ ${ }^{2)}$ Dian Rustyawati, email : dianrustyowati@stitmatuban.ac.id
}

\begin{abstract}
Head Master of school / madrasah as a leader in an educational institution which is the most important element in the course of the organization of educational institutions. As educational leaders, head master/madrasah has a number of tasks and responsibilities that difficult to regulate and set policy and determine the attitude and the purpose of educational institutions. To be able to do his responsibilities optimally, the head master of school / madrasah need to apply the appropriate leadership style to perform the task and responsibilities as leader of school / madrasah. In order that, the style of a person lead will greatly affect the organization that he leads, whether the influence is positive or negative, on the organization. The some reasons of the success of a leader are experienced, courage, initiative, assertive, thoughtful, fair, have tenacity, have a great spirit, able and willing to undertake full responsibility, can guarantee his teamwork and control of the issue and has deep sympathy and understanding.
\end{abstract} Key Word: Headmaster, in school education policy

\section{Pendahuluan}

Kebijakan desentralisasi pendidikan telah memberi peluang besar kepada daerah untuk mengoptimalkan potensinya bagi pembangunan pendidikan sesuai dengan kekhasan daerah, yang keberhasilannya antara lain dapat dilihat dari peningkatan mutu hasil pendidikan tersebut. Ukuran kebermutuan sekolah di Indonesia harus dilihat secara menyeluruh (holistik), jangan dimaknai secara parsial. Keleluasaan pengelolaan pendidikan tersebut tidak hanya dimiliki di tingkat pemerintahan daerah, tetapi juga berimbas kepada kepala sekolah dengan adanya konsep Manajemen Berbasis Sekolah (School Based Management).

Sekolah adalah lembaga yang bersifat kompleks dan unik, bersifat kompleks karena sekolah sebagai organisasi yang didalamnya terdapat berbagai dimensi yang satu sama lain saling berkaitan dan saling menentukan. Sedang sifatnya uniknya adalah menunjukkan bahwa sekolah sebagai organisasi memiliki ciri-ciri tertentu yang tidak dimiliki oleh organisasi lain. 
Ciri-ciri yang menempatkan sekolah memiliki karakter tersendiri yakni dimana terjadi proses belajar mengajar dan tempat terselenggaranya pembudayaan kehidupan manusia. Karena sifatnya yang kompleks dan unik itulah, sekolah sebagai organisasi memerlukan tingkat organisasi yang tinggi. Keberhasilan sekolah adalah keberhasilan kepala sekolah, karena itu kedudukan pemimpin dalam suatu organisasi atau lembaga pendidikan sangat menentukan berhasil tidaknya suatu organisasi dalam mewujudkan suatu tujuan.

Melihat perkembangan sekolah yang semakin kompleks tersebut, maka peran kepala sekolah hendaknya tidak hanya sebagai pemimpin pembelajaran (Instructional leadership), namun harus berupaya untuk mengelola sekolah dalam konteks yang lebih luas, yakni sekolah sebagai proses pendidikan yang melibatkan banyak elemen masyarakat yang berkepentingan didalamnya. Sekolah hendaknya mempunyai sistem yang baik untuk menunjang keberhasilan dan berlangsungnya proses tersebut dengan kondisi lingkungan dlaam hal ini lingkungan sekolah yang menjamin pencapaian kualitas yang diharapkan. ${ }^{1}$

\section{Pembahasan}

\section{Pengertian Kebijakan Kepala Sekolah}

Kebijakan kepala sekolah terdiri dari dua kata yakni kebijakan dan kepala sekolah. Sebelum kita mengetahui makna dari kebijakan kepala sekolah terlebih dahulu kita harus mengetahui makna dari kebijakan itu sendiri. Menurut Indrafachrudi sebagai penulis buku kebijaksanaan pendidikan di Indonesia mengatakan bahwa kebijakan adalah wisdom. Sedangkan kebijaksanaan adalah policy. Kebijakan adalah suatu ketentuan dari pimpinan yang berbeda dengan aturan yang ada, yang dikenakan kepada seseorang karena adanya alasan yang dapat di terima untuk tidak memberlakukan aturan yang berlaku. Sedangkan kebijaksanaan (policy) adalah aturan-aturan yang semestinya dan harus diikuti tanpa pandang bulu, mengikat kepada siapapun yang dimaksud untuk diikat oleh kebijaksanaan tersebut.

Sedangkan menurut Gamage dan Pang menjelaskan kebijakan adalah terdiri dari pernyataan tentang sasaran dan satu atau lebih pedoman yang luas untuk mencapai sasaran tersebut sehingga dapat dicapai yang dilaksanakan bersama dan memberikan kerangka kerja bagi

\footnotetext{
${ }^{1}$ Burhanuddin dkk. Supervisi Pendidikan dan Pengajaran. Malang: Fakultas Ilmu Pendidikan Universitas Negeri Malang.2007, hal 30
} 
pelaksanaan program. Pendapat lain yang dikemukakan oleh Klein dan Murphy mengatakan bahwa kebijakan adalah "seperangkat tujuan-tujuan, prinsip-prinsip serta peraturan-peraturan yang membimbing sesuatu organisasi, kebijakan dengan demikian mencakup keseluruhan petunjuk organisasi“".

Kebijakan adalah suatu kearifan pimpinan kepada bawahan atau masyarakatnya. Pimpinan yang arif dapat saja mengecualikan aturan yang baku, kepada seseorang/ sekelompok orang, jika seseorang/sekelompok orang tersebut tidak dapat dan tidak mungkin memenuhi aturan yang umum tadi. Dengan kata lain ia dapat diperkecualikan. Berdasarkan penjelasan di atas telah menunjukkan kebijakan adalah hasil keputusan-keputusan yang dibuat secara arif dan bijaksana untuk seseorang / sekelompok orang guna untuk mencapai tujuan yang diinginkan dengan melangkah lebih maju ke masa depan. Dan kata kepala sekolah terdiri dari "kepala" dan "sekolah". Kata "kepala" dapat diartikan "Ketua" atau "Pemimpin" dalam suatu organisasi atau suatu lembaga. Sedangkan "Sekolah" adalah sebuah lembaga dimana menjadi tempat menerima dan memberi pelajaran. Kata "Pemimpin" atau "Kepala" itu didefinisikan sebagai: "Suatu kemampuan dan kesiapan seseorang untuk mempengaruhi, membimbing dan menggerakkan atau mengelola orang lain agar mereka mau berbuat sesuatu demi tercapainya tujuan bersama“".

Dari penjelasan diatas dapat disimpulkan bahwa definisi kepala sekolah adalah "Seorang tenaga fungsional guru yang diberi tugas untuk memimpin suatu sekolah dimana diselenggarakan proses belajar mengajar, atau tempat dimana terjadi interaksi antara guru yang memberi pelajaran dan murid yang menerima pelajaran“. Yang dimaksud dengan memimpin pada pengertian diatas yaitu kemampuan untuk menggerakkan segala sumber yang ada pada suatu sekolah sehingga dapat didayagunakan secara maksimal untuk mencapai tujuan yang telah ditetapkan. Dan kata memimpin mengandung konotasi menggerakkan, mengarahkan, membimbing, melindungi, membina, memberikan teladan, memberikan dorongan, dan memberikan bantuan. Jadi, kebijakan kepala sekolah adalah hasil keputusan-keputusan yang dibuat secara arif dan bijaksana oleh kepala sekolah untuk seseorang/sekelompok orang guna untuk mencapai tujuan yang diinginkan dengan melangkah lebih maju ke masa depan. Keberadaan sekolah adalah sebagai lembaga formal dalam penyelenggaraan kebijakan pendidikan nasional atau kebijakan dinas pendidikan kabupaten/kota dalam kekuasaan dan kewenangan kepala sekolah. Seorang kepala sekolah bertanggung jawab dalam melaksanakan kebijakan pendidikan nasional yang telah ditetapkan oleh pemerintah. Dan kepala sekolah 
bertanggung jawab penuh akan sekolah tersebut. Sehubungan dengan hal itu seorang kepala sekolah merupakan kunci keberhasilan suatu lembaga. Karena kepala sekolah adalah seorang pemimpin di lembaganya dan ia yang membawa lembaganya ke arah tujuan yang ingin dicapai oleh lembaga tersebut. Kepala sekolah dikatakan berhasil apabila mereka memahami keberadaan sekolah sebagai organisasi yang kompleks dan unik, serta mampu melaksanakan peranan kepala sekolah sebagai orang yang diberi tanggung jawab untuk memimpin sekolah. Keberhasilan sekolah adalah merupakan salah satu usaha dari kepala sekolah. Dimana kepala sekolah tersebut menjalankan tugas dan tanggung jawabnya dengan baik.

Berawal dari UUD 1945, undang-undang, peraturan pemerintah, keputusan presiden, instruksi presiden, keputusan menteri, sampai kepada peraturan daerah provinsi, peraturan daerah kabupaten dan kota, kemudian diterjemahkan dan dilaksanakan oleh kepala sekolah untuk menyentuh langsung keperluan stakeholders pendidikan, khususnya anak didik. Jadi, setiap kebijakan harus selalu berhubungan dengan kesejahteraan dan pencerdasan masyarakat. Untuk mencapai peningkatan mutu sekolah, maka seorang kepala sekolah sebagai petugas profesional dituntut untuk memformasikan, mengimplementasikan dan mengevaluasi kebijakan pendidikan. Kebijakan sekolah merupakan suatu turunan dari kebijakan pemerintah dalam bidang pendidikan. $^{2}$

jenis kebijakan pendidikan yang mencakup:

1. Penataan/penyusunan tujuan dan sasaran lembaga pendidikan.

2. Mengalokasikan sumber daya untuk dan pelayanan pendidikan.

3. Menentukan tujuan pemberian pelayanan pendidikan.

4. Menentukan pelayanan pendidikan yang hendak diberikan.

5. Menentukan tingkat investasi dalam mutu pendidikan untuk memajukan pertumbuhan ekonomi.

Dari hal tersebut diatas bahwa peran seorang kepala sekolah sangat dibutuhkan dalam lembaga tersebut. Dengan menjalankan fungsi kepala sekolah sebagai leader (pemimpin) dalam mengimplementasikan kebijakan pendidikan dalam semua aspek.

\footnotetext{
${ }^{2}$ Syafaruddin. Efektivitas Kebijakan Pendidikan. Jakarta: Rineka Cipta, 2008. Hal. 75
} 


\section{Tahapan-tahapan Kebijakan Kepala Sekolah}

Dalam suatu kebijakan pendidikan ini terdapat tiga tahap kebijakan yaitu: formulasi, implementasi dan evaluasi. Kepala sekolah sebagai petugas yang profesional dituntut untuk memformulasikan, mengimplementasikan dan mengevaluasi dari kebijakan pendidikan tersebut ada tiga tahapan kebijakan sebagai berikut:

\section{a. Formulasi Kebijakan}

Formulasi adalah perumusan atau pembuatan. Jadi, formulasi kebijakan adalah pembuatan/perumusan suatu kebijakan dalam pendidikan. Berikut adalah tahap-tahap dalam proses pembuatan kebijakan pendidikan:

1. Penyusunan agenda, yakni disini menempatkan masalah pada agenda pendidikan.

2. Formulasi kebijakan, yakni merumuskan alternatif kebijakan untuk mengatasi masalah.

3. Adopsi kebijakan, yakni kebijakan alternatif tersebut diadopsi/diambil untuk solusi dalam menyelesaikan masalah tersebut.

4. Implementasi kebijakan, yakni kebijakan yang telah diambil dilaksanakan dalam pendidikan.

5. Penilaian kebijakan, yakni tahap ini tahap penilaian dalam pembuatan kebijakan dan pencapaian tujuan dalam kebijakan pendidikan.

Dalam pembuatan kebijakan mengandung beberapa isi penting yang dijadikan sebagai pedoman tindakan sesuai yang direncanakan. Adapun isi kebijakan mencakup:

1. Kepentingan yang terpengaruh oleh kebijakan.

2. Jenis manfaat yang akan dihasilkan.

3. Derajat perubahan yang diinginkan.

4. Kedudukan pembuat kebijakan.

5. Siapa pelaksana program.

6. Sumber daya yang dikerahkan

\section{b. Implementasi Kebijakan}

Implementasi kebijakan pada prinsipnya adalah cara yang dilaksanakan agar sebuah kebijakan tersebut dapat mencapai tujuan. Implementasi kebijakan adalah 
serangkaian aktifitas dan keputusan yang memudahkan pernyataan kebijakan dalam pembuatan kebijakan terwujud ke dalam prakteknya/realisasinya.

Terdapat 4 faktor penting dalam mengimplementasikan kebijakan yaitu: komunikasi, sumber daya, sikap pelaksana kebijakan dan struktur birokrasi. Dan untuk mengimplementasikan kebijakan pendidikan ada 2 pilihan langkah yaitu: Yang pertama, secara langsung mengimplementasikan dalam bentuk program-program pendidikan. Yang kedua, dapat melalui kebijakan turunan dari kebijakan pendidikan nasional tersebut.

\section{c. Evaluasi Kebijakan}

Setelah adanya pelaksanaan kebijakan kemudian diadakan pengevaluasian dalam kebijakan pendidikan tersebut. Karena dapat mengetahui sejauh mana pelaksanaan tersebut telah tercapai. Menurut Putt dan Springer bahwa evaluasi adalah langkah menerima umpan balik yang utama dari proses kebijakan.

Evaluasi kebijakan akan memberikan informasi yang membolehkan stakeholders (kebutuhan masyarakat) dapat mengetahui apa yang terjadi dari maksud kebijakan tersebut. Evaluasi yang dimaksudkan disini adalah untuk mengidentifikasikan tingkat keberhasilan pelaksanaan yang dicapai sesuai dengan sasaran. Dan tujuan dari evaluasi kebijakan adalah mempelajari pencapaian sasaran dari pengalaman terdahulu.

\section{Kepemimpinan Kepala Sekolah Yang efektif dalam Penentuan Kebijakan}

Kebijakan pendidikan dapat dikelompokkan menjadi 4 yaitu: Yang pertama, kebijakan yang berkenaan dengan fungsi esensial seperti kurikulum, penetapan tujuan, rekruitmen, penerimaan peserta didik. Yang kedua, kebijakan mengenai lembaga individual dan keseluruhan sistem kependidikan. Yang ketiga, kebijakan yang berkaitan dengan penerimaan, dan penarikan tenaga kerja, promosi, pengawasan, dan penggantian keseluruhan staf. Yang keempat, kebijakan yang berkaitan dengan pengalokasian sumber daya non manusia seperti sumber finansial, gedung dan perlengkapan. Kepala sekolah harus mengetahui problem apa yang terdapat di sekolah tersebut agar dapat ditemukan solusi yang efektif dan efisien dalam penyelesaian masalah tersebut. 
Sebelum lebih jauh menjelaskan tentang kepemimpinan kepala sekolah yang efektif dalam penentuan kebijakan, maka kita harus mengetahui beberapa pihak yang dapat mengambil keputusan yaitu:

1. Kebijakan mengenai standar kurikulum menjadi kewenangan menteri pendidikan.

2. Kebijakan mengenai alokasi anggaran menjadi tanggungjawab pemerintah daerah provinsi dan kabupaten / kota yang didalamnya termasuk legislatif, dan

3. Kebijakan pembelajaran ada pada sekolah yang dikendalikan oleh kepala sekolah. Kebijakan pembelajaran ini seperti: mengelaborasi kurikulum menjadi bahan ajar pada setiap mata pelajaran, menyediakan kelengkapan pengajaran, menyiapkan ruang kelas yang layak dan nyaman dipakai, melakukan supervisi kepada guru dan membina pertumbuhan jabatan melalui pelatihan yang sesuai dengan kebutuhan. ${ }^{3}$

Oleh karena itu, sekolah diperlukan seorang pemimpin yang efektif dalam penentuan kebijakan dalam pendidikan. Kepemimpinan yang efektif adalah kepemimpinan yang mampu menumbuhkan dan mengembangkan usaha kerjasama serta memelihara iklim yang kondusif dalam kehidupan organisasi. Setiap orang sebagai anggota suatu kelompok dapat memberikan sumbangannya untuk kesuksesan kelompoknya.

Kepemimpinan kepala sekolah yang efektif mampu merumuskan program dan melaksanakan kegiatan mengutamakan partisipasi seluruh anggotanya. Seorang kepala sekolah harus mampu memotivasi, mendorong, menggalang, mengarahkan, membimbing, mensupervisi seluruh pendidik dan tenaga kependidikan sehingga dapat melaksanakan kebijakan dengan benar. Seorang pemimpin juga harus arif/bijaksana dalam mengambil kebijakan dan keputusan dalam tugas-tugas administratif serta dapat bertanggung jawab apabila tujuan belum tercapai.

Tugas utama pemimpin adalah pengambilan keputusan.yang dilakukan secara rasional (efektif dan efisien) oleh kepala sekolah. Dan pertimbangan keputusan tersebut harus dilihat dari: tujuan organisasi, sumber daya yang ada, informasi yang lengkap tentang fungsi sistem kerja, pengalokasian sumber dana didasarkan pada prioritas dan harus memahami pengelolaan dana.

\footnotetext{
${ }^{3}$ Sagala, Syaiful. Kemampuan Profesional Guru dan Tenaga Kependidikan. Bandung: Alfabeta. 2009, hal. 102
} 


\section{Implementasi Kebijakan Kepala Sekolah}

Implementasi kebijakan merupakan tahap kedua setelah pembuatan/pengembangan kebijakan. Tolak ukur keberhasilan kebijakan pendidikan adalah terdapat pada implementasi kebijakan itu sendiri. Istilah implementasi adalah dapat diartikan sebagai "penerapan, pelaksanaan hingga menjadi terwujud“. Jadi, Implementasi kebijakan adalah pelaksanaan/ penerapan suatu kebijakan.

Implementasi kebijakan pada dasarnya adalah hal yang menentukan dalam kebijakan publik. Dan kebijakan pendidikan ini merupakan turunan dari kebijakan publik. Pada desentralisasi pendidikan sekarang ini memberikan peluang bagi kebijakan sekolah di daerah. Kebijakan pendidikan di daerah di dapat dari Dewan Pendidikan Kabupaten dan Kota. Yang selanjutnya kebijakan tersebut diberikan oleh kepala sekolah untuk membuat kebijakan sekolah bersama dengan staf, pengawas, dan komite sekolah.

Seorang kepala sekolah memiliki kewenangan dalam membuat dan mengimplementasikan kebijakan yang didapat dari pimpinan yang lebih tinggi sesuai dengan visi, misi, dan sasaran sekolah dengan mengacu kepada sumber daya yang ada di dalam dan di luar sekolah. Suatu kebijakan sekolah merupakan suatu hal yang sangat penting bagi siswa dan para guru karena sangat berkaitan dengan pembelajaran dalam rangka peningkatan efektifitas sekolah.

Manfaat dari kebijakan adalah untuk meraih kepuasan harapan masyarakat sebagai bagian penting stakeholders pendidikan. Kepala sekolah sebagai pemimpin mempunyai peranan yang sangat penting dalam melaksanakan kebijakan pimpinan puncak untuk mengelola seluruh sumber daya yang dapat mendukung pencapian keunggulan sekolah.

Untuk melaksanakan suatu kebijakan dengan baik maka diperlukan pemimpin yang efektif. Dan pemimpin yang efektif mempunyai ciri-ciri sebagai berikut:

1. Mempunyai rasa tanggung jawab.

2. Peduli akan penyelesaian tugas

3. Energik

4. Tekun

5. Mau memikul resiko

6. Percaya diri

7. Mempunyai kemampuan mengkoordinasi usaha orang lain dalam mencapai tujuan. 
Kepala sekolah dalam membuat kebijakan baru adalah menciptakan keadaan baru dengan melibatkan personel sekolah didalamnya. Dan kepala sekolah bertanggung jawab penuh akan hal itu karena kebijakan baru yang dibuat tersebut harus membawa visi dan misi perubahan ke arah yang lebih berkualitas/inovatif. Adapun kebijakan-kebijakan yang dibuat oleh kepala sekolah sebagai berikut:

\section{a. Mengadakan Pembinaan Profesional}

Kebijakan kepala sekolah yang diambil salah satunya dengan cara mengadakan Pembinaan profesional adalah usaha memberi bantuan kepada guru guna memperluas pengetahuan, meningkatkan keterampilan mengajar dan menumbuhkan sikap profesional mereka sehingga menjadi lebih profesional dalam mengelola kegiatan pembelajaran dalam rangka pencapaian tujuan pendidikan. Kegiatan pembinaan profesional ini meliputi: adanya program penataran seperti adanya seminar, diskusi, pelatihan, pembinaan teknis / pembimbingan oleh tutor / tutorial dalam kelas maupun dalam kelompok kerja guru (KKG).

Pembinaan profesional para guru dalam rangka meningkatkan kemampuan mengajar dapat dilakukan oleh kepala sekolah dengan melalui teknik-teknik sebagai berikut:

1. Kunjungan kelas yang dilaksanakan oleh kepala sekolah untuk mengetahui kualitas pelaksanaan proses belajar mengajar.

2. Pertemuan pribadi untuk berdialog/bertukar pikiran antara kepala sekolah dengan guru dan pertemuan itu bersifat informal.

3. Rapat dewan guru yang didalamnya pertemuan semua guru dan kepala sekolah.

4. Kunjungan antar kelas.

5. Kunjungan antar sekolah yang dilakukan guru-guru dari sekolah tertentu ke sekolah lain.

\section{b. Pembentukan Adanya Asosiasi Guru Untuk Peningkatan Mutu Pendidikan (AGPMP)}

Selain dari hal yang telah disebutkan diatas kebijakan yang dilakukan oleh kepala sekolah adalah dengan mengadakan AGPMP. Atau sering kita sebut dengan MGMP (Musyawarah Guru Mata Pelajaran).

MGMP ini adalah forum/wadah kegiatan profesional guru mata pelajaran sejenis di sanggar. Musyawarah ini mencerminkan kegiatan dari, oleh dan untuk guru. MGMP/AGPMP ini beranggotakan guru-guru sebidang/antar bidang, dimana mereka 
merencanakan, melaksanakan, dan mengawasi program-program yang berkaitan dengan upaya peningkatan mutu pendidikan bagi peningkatan efektifitas mutu sekolah. Tujuan AGPMP. ${ }^{4}$ adalah:

1. Untuk menumbuhkan kegairahan guru untuk meningkatkan kemampuan dan keterampilan dalam mempersiapkan, melaksanakan, dan mengevaluasi program kegiatan belajar mengajar (KBM) dalam rangka meningkatkan sikap percaya diri sebagai guru.

2. Untuk menyetarakan kemampuan dan kemahiran guru dalam melaksanakan kegiatan belajar mengajar sehingga dapat menunjang usaha peningkatan dan pemerataan mutu pendidikan.

3. Untuk mendiskusikan permasalahan yang dihadapi oleh guru dan mencari penyelesaian yang sesuai dengan karakteristik mata pelajaran, guru, kondisi dan lingkungan sekolah.

4. Membantu guru untuk memperoleh informasi teknis edukatif.

5. Saling berbagi informasi dan pengalaman dalam rangka menyesuaikan perkembangan ilmu pengetahuan dan teknologi.

\section{c. Mengadakan Rapat Guru}

Kebijakan yang dilakukan kepala sekolah dalam meningkatkan kompetensi guru dapat dilakukan dengan cara mengadakan rapat guru. Adapun rapat guru banyak sekali jenisnya (dalam Sehertian, 1981) diantaranya:

1. Menurut Tingkatannya

- Staff meeting yaitu rapat guru-guru dalam satu sekolah tersebut.

- Rapat guru bersama dengan orang tua murid dan murid-murid.

- Rapat guru dari beberapa sekolah yang bertetangga

2. Menurut Waktunya

- Rapat permulaan dan akhir tahun

- Rapat periodik (dalam beberapa periode tertentu)

3. Menurut Bentuknya

4 Departemen Pendidikan dan Kebudayaan. Pedoman Penyelenggaraan Musyawarah Guru Mata Pelajaran. Jakarta: Direktorat Pendidikan Menengah Umum.1998. hal. 46 
- Diskusi

- Seminar

- Workshop

\section{d. Adanya Studi Kelompok Antar Guru}

Yakni guru-guru dalam mata pelajaran sejenis berkumpul bersama untuk mempelajari suatu masalah/sejumlah bahan pelajaran. Pokok bahasan telah ditentukan dan diperinci dalam garis-garis besar/dalam bentuk pertanyaan-pertanyaan pokok yang telah disusun secara teratur.

Mengikuti workshop (Lokakarya). Workshop adalah suatu device dalam in-service education, cara belajar sesuatu dengan menggunakan sharing of ideas, prosedure give and take, suatu sistem kerja yang selaras dengan jiwa gotong-royong.

Kepala sekolah sebagai seorang pemimpin harus mampu:

1. Mendorong timbulnya kemauan yang kuat dengan penuh semangat dan percaya diri para guru/staf dan siswa dalam melaksanakan.

2. Memberikan bimbingan dan pengarahan para guru, staf dan para siswa serat memberikan dorongan memacu dan berdiri di depan demi kemajuan dan memberikan inspirasi sekolah dalam mencapai tujuan.

Kepala sekolah dalam mengambil keputusan berupa kebijakan itu terkandung nilainilai manusia yang secara psikologis dan pedagogis, dapat membawa pada kehidupan sosial yang tentram dan damai dengan rasa solidaritas sosial yang semakin kokoh. Pada hakekatnya pengambilan keputusan menurut Siagian (1985) adalah suatu pendekatan sistematis terhadap suatu masalah yang dihadapi. Pendekatan yang sistematis itu menyangkut pengetahuan hakekat daripada masalah yang dihadapi itu, pengumpulan fakta dan data yang relevan dengan masalah yang dihadapi, analisis masalah dengan menggunakan fakta dan data bukan keinginan subyektif dari pemimpin. ${ }^{5}$

\footnotetext{
${ }^{5}$ Wahjosumidjo. Kepemimpinan Kepala Sekolah. Jakarta: Grafindo Persada.2002.hal. 80
} 


\section{Kesimpulan}

Pendidikan sangat penting keberadaanya bagi kelangsungan hidup sebuah negara bangsa. Untuk memperoleh sumber daya manusia yang unggul dibutuhkan satu proses pendidikan yang baik. Proses pendidikan yang baik bukan hanya menjadi tanggung jawab lembaga penyelenggara pendidikan semata, tetapi juga harus didukung perannya oleh masyarakat dan pemerintah yang dalam hal ini bertindak sebagai pemegang amanah tertinggi dari UUD 1945 untuk mencerdaskan bangsa Indonesia.

Seiring bergulirnya reformasi di negara Indonesia yang menuntut otonomi daerah maka secara bertahap pun kewenangan penyelenggaraan pendidikan diserahkan kepada tiap-tiap pemerintah daerah. Dengan diserahkannya kewenangan tersebut kepada pemerintah daerah berarti telah ada keleluasaan kepada daerah untuk menjalankan aktivitas pelayanan publik tanpa harus banyak terpaku pada aturan-aturan yang telah di buat oleh pemerintah pusat.

Implementasi kebijakan merupakan tahap kedua setelah pembuatan/pengembangan kebijakan. Tolak ukur keberhasilan kebijakan pendidikan adalah terdapat pada implementasi kebijakan itu sendiri. Istilah implementasi adalah dapat diartikan sebagai "penerapan, pelaksanaan hingga menjadi terwujud“. Jadi, Implementasi kebijakan adalah pelaksanaan/ penerapan suatu kebijakan.

Seorang kepala sekolah memiliki kewenangan dalam membuat dan mengimplementasikan kebijakan yang didapat dari pimpinan yang lebih tinggi sesuai dengan visi, misi, dan sasaran sekolah dengan mengacu kepada sumber daya yang ada di dalam dan di luar sekolah. Suatu kebijakan sekolah merupakan suatu hal yang sangat penting bagi siswa dan para guru karena sangat berkaitan dengan pembelajaran dalam rangka peningkatan efektifitas sekolah.

Implementasi kebijakan kepala sekolah sangat berperan penting dalam membantu meningkatkan kualitas pendidikan. Dengan cara mengadakan Pembinaan Profesional, pembentukan adanya Asosiasi Guru untuk Peningkatan Mutu Pendidikan (AGPMP), mengadakan Rapat Guru, Adanya Studi Kelompok Antar Guru dan Mengikuti workshop (Lokakarya).

\section{Referensi}


Abdurrahman. (1987). Beberapa Pemikiran Tentang Otonomi Daerah. Jakarta: Media Sarana Press

Burhanuddin dkk. 2007. Supervisi Pendidikan dan Pengajaran. Malang: Fakultas Ilmu Pendidikan Universitas Negeri Malang.

Danuredjo. (1977). Otonomi Indonesia Ditinjau dalam Rangka Kedaulatan. Jakarta: Penerbit Laras

Departemen Pendidikan dan Kebudayaan. 1988. Pedoman Penyelenggaraan Musyawarah Guru Mata Pelajaran. Jakarta: Direktorat Pendidikan Menengah Umum.

Koesoemahatmadja. (1979). Pengantar ke Arah Sistem Pemerintahan di Daerah di Indonesia. Bandung: Binacipta

Muhdi, Ali. (2007). Konfigurasi Politik Pendidikan Nasional. Yogyakarta. Pustaka Fahima.

Nugroho, D. Riant. (2000). Otonomi Daerah, Desentralisasi Tanpa Revolusi. Jakarta: PT Elex Media Computindo

Sagala, Syaiful. 2009. Kemampuan Profesional Guru dan Tenaga Kependidikan. Bandung: Alfabeta.

Sahertian, . Piet A. 1981. Prinsip dan Teknik Supervisi Pendidikan. Surabaya: Usaha Nasional.

Saleh, Syarif. (1963). Otonomi dan Daerah Otonom. Jakarta: Penerbit Endang

Suryono, Yoyon. (2000). Arah Kebijakan Otonomi Pendidikan Dalam Konteks Otonomi Daerah. Yogyakarta: FIP UNY

Syafaruddin. (2008). Efektivitas Kebijakan Pendidikan. Jakarta: Rineka Cipta

Wahjosumidjo. 2002. Kepemimpinan Kepala Sekolah. Jakarta: Grafindo Persada.

Wayong J. (1979). Asas dan Tujuan Pemerintahan Daerah. Jakarta: Penerbit Djambatan 